\title{
RECREATION IN THE CITY-A PART OF CULTURAL ECOSYSTEM SERVICES
}

\author{
ZDENKA RÓZOVÁ, MARTINA TURANOVIČOVÁ*, SIMONA STAŠOVÁ
}

Constatine the Philosopher University in Nitra, Faculty of Natural Sciences, Department of Ecology and Environmental Sciences, Tr. A. Hlinku 1, 94974 Nitra, Slovak Republic; e-mail: martina.turanovicova@ukf.sk

"Author for correspondence

\begin{abstract}
Rózová Z., Turanovičová M., Stašová S.: Recreation in the city-A part of cultural ecosystem services. Ekológia (Bratislava), Vol. 39, No. 2, p. 190-200, 2020.

Cultural ecosystem services (CES) are mainly intangible benefits, obtained by aesthetical and other experiences, recreation, learning and spiritual enrichment, or by the ability to distinguish values. In other words, what makes a service 'cultural' is its 'non-economical' character. CES are ecosystem services with direct impact on the quality of life in urban systems, and they are directly appreciated by inhabitants and visitors of these urban systems (Plieningeret al., 2013; Zulian et al., 2018). In order to satisfy the needs and expectations of the wider urban community, a 'broader portfolio of areas' is needed, which can meet the expectations of different users, from children to older adults. The new methodological approach tested on three model areas in the city of Nitra in the housing estate Chrenová was used to establish the level of benefits provided by existing vegetation areas in urban environment in terms of recreation as a CES. Following data were collected: the quality of vegetation, spatial design, management of vegetation elements, selected environmental aspects, available amenities and architectural elements needed for recreation. In our article, we present the assessment of vegetation in relation to the provision of recreation as a CES. Our results show that the assessed areas can be classified in the category of average to low provision of benefits related to recreation. Vegetation on area $\mathrm{P} 1$ is in good condition, mainly the quality of trees and shrubs was assessed as very good (4). Other areas (P2 and P3) assessed provide only low levels of benefits derived from recreation as one of the CES. This was caused by some vegetation deficiencies (mainly related to horticultural and compositional aspects). Methodological approach can be used for different vegetation areas in urban environment and after suitable modifications (e.g. adding other components for assessment) also for different cultural ecosystems services. The results can be used in landscape planning documents or in other types of documents dealing with the quality of vegetation in urban environment.
\end{abstract}

Key words: CES, recreation, public green spaces, vegetation.

\section{Introduction}

Cultural ecosystem services (CES) can be defined according to MA (2005) as the intangible benefits that people derive from ecosystems. CICES (2018) understands them as the characteristics of elements of nature that provide opportunities for people to derive cultural goods or benefits. 
An integral part of human life in urbanised environments is vegetation. In the urban environment, we refer to it as urban ecosystems, which enrich the surroundings and life through their benefits. Vegetation as a biotic component serves to balance but also to complement abiotic components. Public greenery is one of the most important elements that provides urban ecosystem services, and it is regarded as a subject that is accessible to all residents. Public greenery represents a piece of nature for all residents (De La Barrera, 2016; Murgaš, 2018). Vegetation areas are an important component of urban green infrastructure, and they provide a wide range of ecosystem services, including cultural services such as recreation and recovery (Daniel et al., 2012; Izakovičová et al., 2017).

According to Špulerová (2006), vegetation has a positive impact in the urbanised environment especially on improving microclimate, ecological stability, elimination of threats to the urban environment and biodiversity in cities, such as climate change or unstable hydrological cycle, on some entities related to sustainable development, for example, environmental education, public health, recreational services, psychological and aesthetic functions.

\section{Material and methods}

\section{Research sites}

On the left bank of the Nitra River, the Chrenová I housing estate was built between 1964 and 1968, supervised by the architect Michal Maximilian Scheer. The quality of this residential area is also confirmed by the fact that it is inscribed in the UNESCO urban-architectural book. The residential area is dominated by continuous areas of residential greenery around the river and residential buildings. The meandering structure of the low-rise housing structure defines interesting block spaces (Jarabica, 2011).

The research is carried out in the localities of Chrenová I, II and III housing estates in Nitra (Fig. 1). Three areas are selected (P1, P2 and P3), which have the best potential for leisure, sport, recreation and so on.

\section{Methodological approach}

The aim of the research was to create a new methodological approach to analysis of CES in terms of recreation in urbanised environment. The quality (value) of elements and factors (quality of vegetation, spatial composition, environmental factors, management and equipment) on selected vegetation areas determines the level of benefit, based on which the provision of recreational services is determined (Turanovičová, Rózová, 2017). This approach builds on already existing CES assessment methods (Piscová et al., 2018). The method is applicable to all vegetation areas in urbanised environments to determine the current status of providing benefits related to CES - specifically recreation. It can be complemented from different perspectives and from different areas and needs (e.g. accessibility). In this article, we deal with the quality of vegetation (trees and shrubs, lawn and flower beds) for recreational use and for determining the level of benefit that vegetation provides to inhabitants.

The methodological approach is based on the work of Bastian et al. (2012) and Burkhard et al. $(2009,2012)$. The value of ecosystem services is expressed in a relative point scale of $0-5$, where zero means 'zero ecosystem capacity to provide the selected ecosystem service', whereas value 5 represents 'very high capacity (quality) of ecosystem'.

The methodological approach includes analyses and assessments of individual vegetation elements on vegetation areas in housing estates. A value-creating process has been created, in which value means quality from a human perspective. A point scale of $0-5$ was used to determine the quality of the monitored vegetation elements, where 0 means no quality of vegetation elements and 5 means the highest quality. The quality values have been assigned a benefit rate provided by the vegetation elements for recreation (Turanovičová, Rózová, 2018).

\section{Analysis of vegetation elements quality}

The vegetation quality analysis was carried out by assigning numerical values $(0-5)$ to vegetation elements (trees and shrubs, flower beds and grass areas). Numerical values used for tree inventory according to Machovec (1982) were 


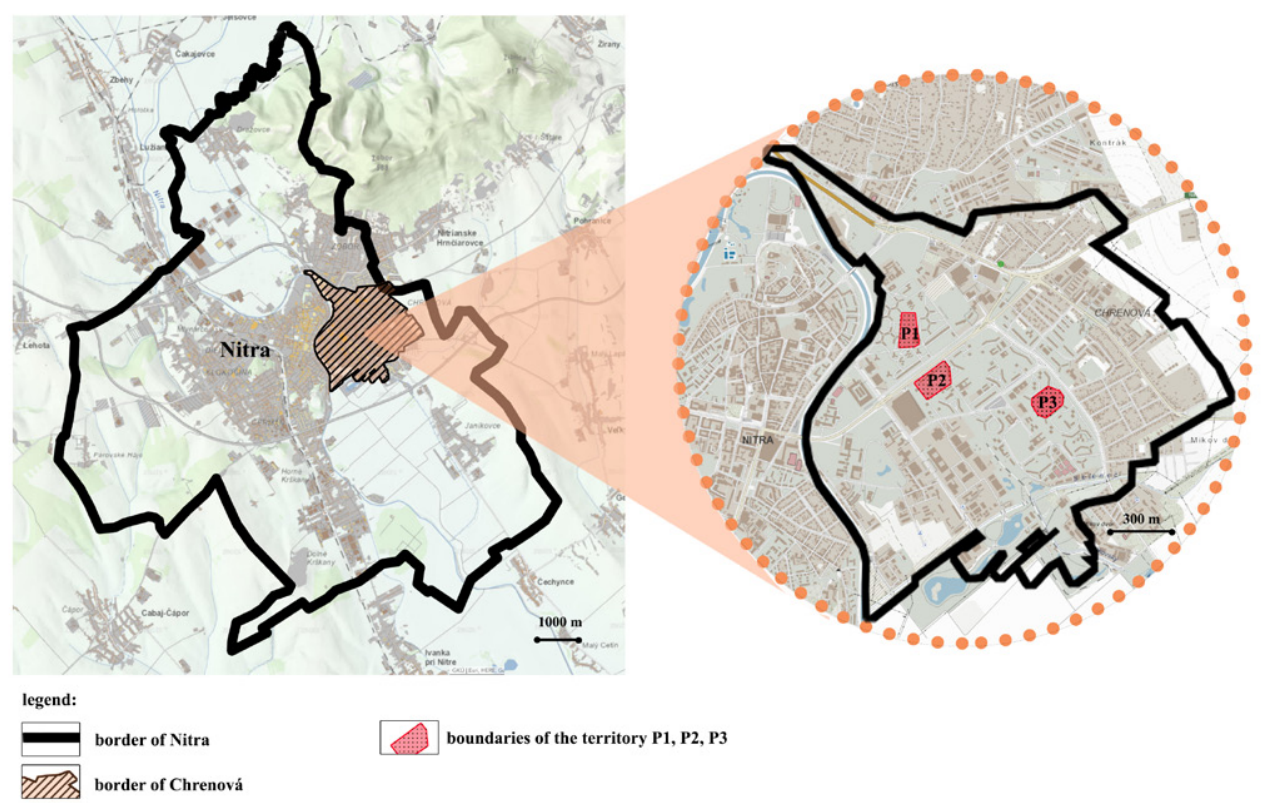

Fig. 1. Research localities.

used for this analysis. The numerical values reflect the quality of analysed vegetation elements. The highest quality trees are assigned a value of 5 and the least quality a value of 1 . If there are no trees and shrubs on the area, a value of 0 is assigned. Parameters of horticultural value and health status were chosen, supplemented by the composition value according to the method of Kubišta (2008) adjusted for the needs of our evaluation, where 0 is the vegetation without compositional value, 1 represents the lowest value of the vegetation or elements in the composition, 5 represents the best applicability of given vegetation in the spatial composition. The analytical data about the vegetation elements obtained from the field survey are collected and then used in the evaluation. Individual vegetation elements together form one whole; therefore, they are evaluated by rounded average in individual parameters.

\section{Assessment of vegetation elements}

The aim of the evaluation is, based on the analytical data that indicated the quality of individual elements, to evaluate the extent of benefits obtained from the monitored area for the needs of recreation within the framework of CES. The level of benefit is manifested in the use of the area for recreational, leisure, sports and other activities. After evaluation, the individual elements are assigned a level of benefit within the framework of CES.

Assigning the level of benefits to quality values of vegetation elements

The analysis of vegetation quality in the monitored areas is carried out by assigning numerical values to vegetation elements (trees and shrubs, lawn and flower beds). The quality of vegetation corresponds to the level of benefit expressed in points. That is, the higher the quality of vegetation on the surface, the higher the utilisation (benefit) rate, in our case the benefit of recreational services. Therefore, a numerical value of 0 is assigned to a zero level of benefit. The highest quality of vegetation $(4,5)$ is assigned the highest benefit level $(3)$. The quality assessed as 1 and 2 is assigned the value of 1 , and the quality level of 3 is assigned a value of 2 . 
Categories of levels of benefits provided by vegetation to recreational ecosystem service in terms of quality of vegetation elements

The overall benefit levels of the monitored area in terms of vegetation are divided into four categories. It is the sum of the points assigned to benefits from vegetation elements. It expresses the degree to which vegetation provides benefits in terms of the recreational ecosystem service:

4. 9-8 points - a high level of benefits related to recreational cultural ES

- vegetation of the highest quality, representation of all analysed vegetation elements in excellent health condition, vegetation is well placed from the compositional and horticultural point of view, high representation of native species, 3. 7-5 points - average level of benefits related to recreational cultural ES

- vegetation of average quality, one vegetation storey is missing, health condition can be disturbed, but it has the potential to perform its functions after professional treatment, compositional and horticultural aspects have deficiencies that can be treated,

2. 4-2 points - low level of benefits related to recreational cultural ES

- low-quality vegetation, one or two storeys missing, health condition unsuitable, vegetation does not meet the requirements to provide CES,

1. 1-0 points - very low level of benefits related to recreational cultural ES

- unsatisfactory vegetation quality, only one storey can be represented, in poor health condition without compositional and horticultural value, areas very damaged, untreated.

\section{Results}

\section{Analysis of quality of vegetation elements in area $P 1$}

The vegetation area P1 at Chrenová 1 is located between the streets Ludovíta Okánika and Lomnická. It is located in the middle of the residential complex. It is attractive for families with children, thanks to the traffic playground (Fig. 2). Relaxation areas, sidewalks and a tavern provide leisure options for different ages. There is a large amount of predominantly deciduous trees. The grass areas are located along the edges of the vegetation area. They are little used. The area does not provide opportunities for a variety of different recreational, sports and leisure activities, which negatively affects visit rate.

The vegetation elements on the P1 area are of high (4) to average quality (3) (Table 1). The highest quality ratings (4) have trees and shrubs. Planted trees were assessed as average quality from the horticultural point of view. The plants are of average value; about half of the area includes native species with typical species and growth attributes. In particular, the health condition can be assessed as particularly good, with high quality (4). The occurrence of diseases and pests is rare; the vegetation is partly dried, concerning up to one-fifth of the vegetation. The trees are appropriately deployed in terms of composition.

In particular, grass areas have deficiencies, especially from the point of view of horticulture and health, having poor quality (2). The lawn is damaged; the growth characteristics are changed for more than $50 \%$ of the lawn. Considering health aspects, three-fifth of the area is dry, the damage due to diseases is $25-50 \%$. Flower beds are missing, which negatively affects the assessment.

\section{Analysis of quality of vegetation elements in area P2}

The vegetation area P2 is located between the streets Lesná and Lipová. The area is situated near the busy main road Tr. A. Hlinku and shopping centre Centro Nitra. There is a playground and fitness 


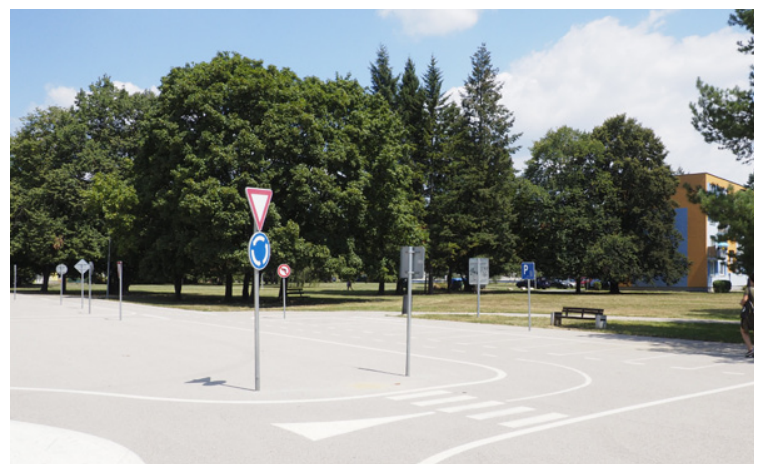

Fig. 2. Traffic playground.

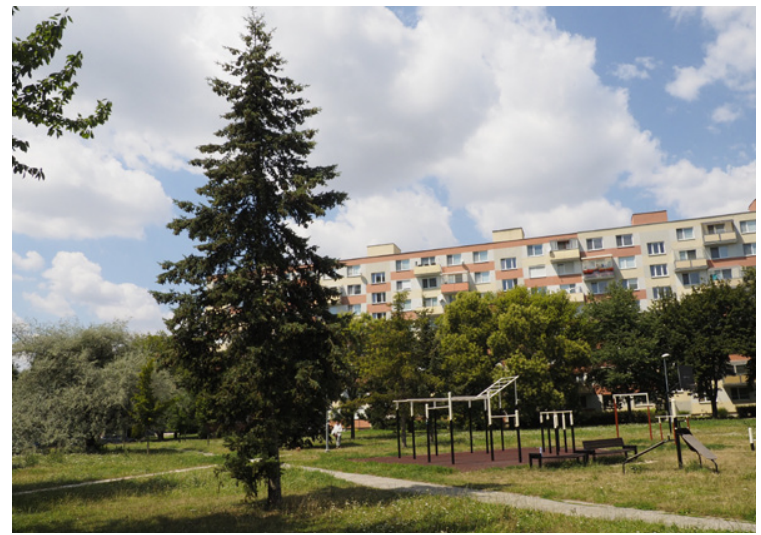

Fig. 3. Fitness elements.

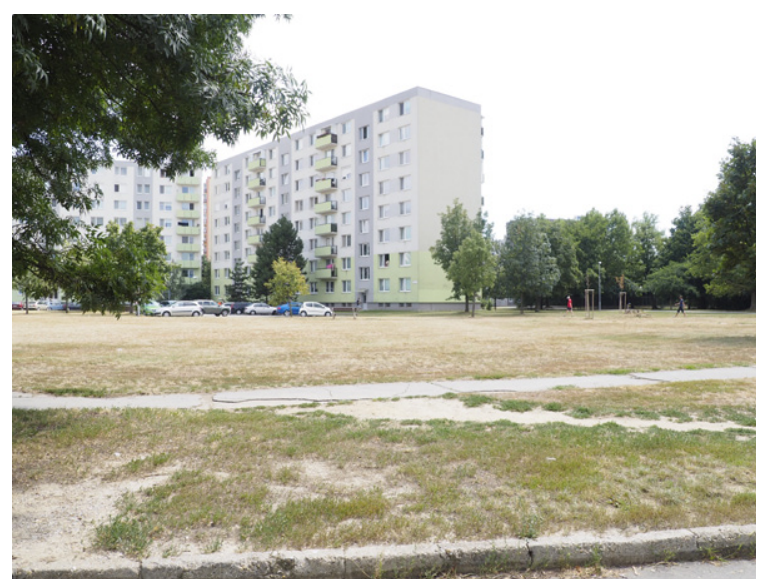

Fig. 4. Dried lawn. equipment Street Workout Park Nitra (Fig. 3). The whole area is planted with many predominantly deciduous trees.

Analysis (Table 1) shows that the quality is average (3) to low (2). Trees and shrubs have the highest (4) value in the health category. There is rare occurrence (up to 5\%) of diseases and pests in trees; vegetation is partly dried, concerning up to one-fifth of the vegetation volume, the stability is not disturbed. The horticultural value is average (3). Approximately half of the area includes native species with typical species and growth characteristics. From the compositional point of view, the vegetation covers about half of the area, and it has a long-term potential to fulfil various functions, and the potential for further use of the vegetation is $40-60 \%$. Both horticultural value and health conditions of the lawn are of poor quality (2). The lawn is damaged. The growth characteristics are changed on more than $50 \%$ of the vegetation. More than three-fifth of the area are dried. After the treatment, it can be left on the surface. The occurrence of diseases is rare; the biggest deficiency is desiccation. The lawn covers $20-30 \%$ of the area; the usability of the lawn in the future is $40-60 \%$. The absence of flower beds negatively affects the overall vegetation assessment of the monitored areas.

Analysis of quality of vegetation elements in area $P 3$

The vegetation area P3 on Chrenová III is bordered by Karpatská and 
Bajkalská streets. It connects to an important pedestrian communication linking the shopping centre to the former Lipa cinema and housing units. The vegetation is not properly placed in terms of composition, the central grass area is exposed to sunlight and is dry in summer months (Fig. 4).

On the basis of our analysis (Table 1), the vegetation on the area P3 has the biggest deficiencies of all the monitored areas. Trees and shrubs are of low quality (2) in terms of horticulture and composition. The quality of trees is below average, with significant predominance of non-native species (approximately two-third). Vegetation covers only $30 \%$ of the area; the usability of vegetation is $20-40 \%$. The health of woody plants is average. Grass areas have a low rating in all parameters (2). The lawn is damaged, weedy on $50-80 \%$ and dried, covering $70 \%$ of the area

T a b l e 1. Analysis of quality of vegetation elements on areas P1, P2 and P3.

\begin{tabular}{|c|c|c|c|c|c|c|c|c|c|c|c|c|}
\hline \multirow{3}{*}{ Vegetation elements } & \multicolumn{9}{|c|}{$\begin{array}{c}\text { Analysis of quality of vegetation elements in } \\
\text { different parameters }\end{array}$} & \multirow{2}{*}{\multicolumn{3}{|c|}{$\begin{array}{c}\text { Average } \\
\text { quality of } \\
\text { vegetation } \\
\text { elements }\end{array}$}} \\
\hline & \multicolumn{3}{|c|}{$\begin{array}{l}\text { Horticultural } \\
\text { value }\end{array}$} & \multicolumn{3}{|c|}{$\begin{array}{c}\text { Health } \\
\text { condition }\end{array}$} & \multicolumn{3}{|c|}{$\begin{array}{l}\text { Compositional } \\
\text { value }\end{array}$} & & & \\
\hline & P1 & P2 & P3 & P1 & $\mathbf{P 2}$ & P3 & P1 & $\mathbf{P 2}$ & P3 & P1 & P2 & P3 \\
\hline Trees and shrubs & 3 & 3 & 2 & 4 & 4 & 3 & 4 & 3 & 2 & 4 & 3 & 2 \\
\hline Grass areas & 2 & 2 & 2 & 2 & 2 & 2 & 4 & 3 & 2 & 3 & 2 & 2 \\
\hline Flower beds & 0 & 0 & 0 & 0 & 0 & 0 & 0 & 0 & 0 & 0 & 0 & 0 \\
\hline Average quality of parameters & 2 & 2 & 1 & 2 & 2 & 2 & 3 & 2 & 1 & - & - & - \\
\hline
\end{tabular}

Notes: 5 - very high quality; 4 - high quality; 3 - average quality; 2 - low quality; 1 - very low quality; 0 - without vegetation elements.

\section{Quality of vegetation elements in areas $P 1, P 2$ and $P 3$}

Vegetation in the monitored areas has average (3) to low (2) quality (Fig. 5). Only on area P1, the trees and shrubs are in the category of high quality (4). The quality of individual vegetation elements varies across the areas. The character of planting is similar, the planting comes from the period of construction of the housing estate Chrenová. Coniferous species of Pseudotsuga menziesii (Mirb.) that are represented in each of the monitored areas were planted in large quantities. Their planting is not appropriate in terms of climatic zone. The highest quality of trees and shrubs is on the area P1, with the value of 4, meaning 'high quality'. Area P2 has an average quality (3) of planted trees and shrubs. The greatest deficiencies are on the area $\mathrm{P} 3$ in terms of species composition and unsuitable compositional distribution.

The lawn has a quality in the range of 3-2, depending on the area. Area P1 has the best rating among the monitored areas. However, it is only average quality. The lawn in areas P2 and $\mathrm{P} 3$ is dry. In the area P3, the lawn has an unsuitable ratio to tree vegetation. It covers more than two-third of the area, resulting in sunburn and subsequent drying.

Flower beds are not found on any of the areas. Therefore, we can say that, on the monitored areas, the quality of trees and shrubs is better than the quality of grass areas, area P1 


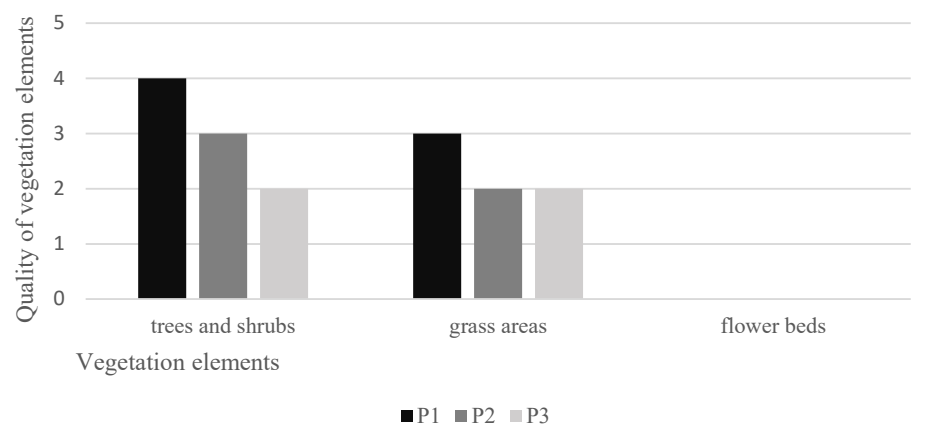

Fig. 5. Quality of vegetation elements on areas P1, P2 and P3.

Notes: 5 - very high quality; 4 - high quality; 3 - average quality; 2 - low quality; 1 - very low quality; 0 - without vegetation.

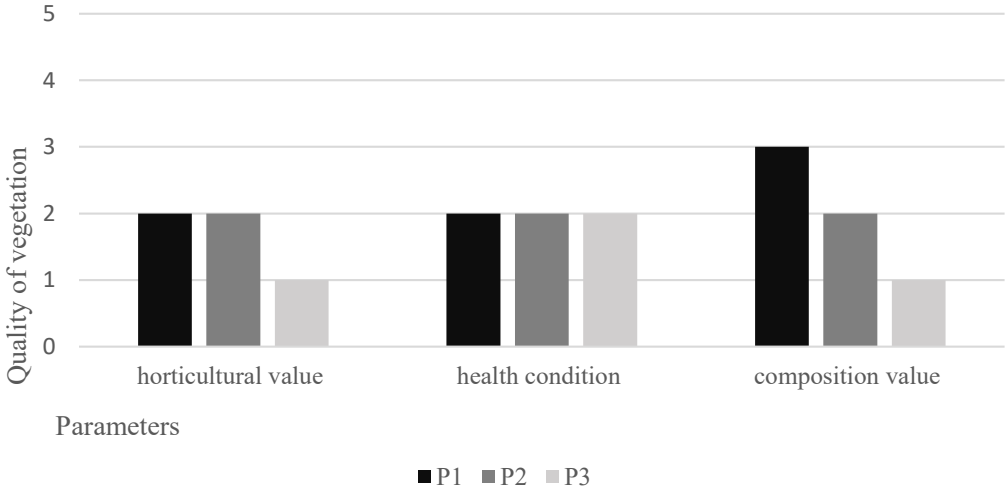

Fig. 6. Quality of vegetation by different parameters in areas P1, P2 and P3.

Notes: 5 - very high quality; 4 - high quality; 3 - average quality; 2 - low quality; 1 - very low quality; 0 - without vegetation.

is better than P2 and P3. The quality of trees, shrubs and lawns on the P3 surface is of poor quality (2) and is the worst of the monitored areas.

\section{Quality of vegetation by different parameters in areas $P 1, P 2$ and $P 3$}

The monitored areas can be analysed not only from the point of view of the quality of vegetation elements but also from the point of view of the parameters - the horticultural value of the overall vegetation stand, its health condition and the composition value of the stand. Figure 6 shows the comparison of quality of the vegetation in terms of different parameters on three areas. Surfaces are of poor quality (2) in the monitored parameters. An exception is the area $\mathrm{P} 1$, which has an average vegetation quality from a compositional point of view (3). Overall, we can say that the quality of vegetation in individual parameters is low. 
Assigning the level of benefit to the quality values of vegetation elements and the category of utility rates provided by vegetation on areas $P 1, P 2$ and $P 3$

The utility rate provided by the vegetation area based on the quality of the vegetation elements is different on the areas P1, P2 and P3. From Fig. 7, we can see that the best result is on the area P1 (with 5 points), where the utility rate falls into the category 3 - average level of benefits provided by the vegetation. Vegetation is of average quality in terms of all evaluated parameters. The average horticultural value of trees manifests itself in growth characteristics such as habitus and species nativeness. The biggest deficiency is the occurrence of non-native species P. menziesii (Mirb.). From a health point of view, vegetation is in a good condition, which is reflected in appearance, fulfilment of functions (microclimate improvement, dust absorption and shadowing) and providing benefits to the population. In terms of the composition, the most suitable from three monitored areas is the area P1, with the greatest future usability.

The areas P2 (number of points: 3) and P3 (number of points: 2) are in category 2 a low level of benefits provided by vegetation. A common drawback in these areas is the inappropriate composition of woody plants. Area P2 has spots with overgrown vegetation and, conversely, P3 has few trees. The absence of flower beds negatively affects the assessment of all three studied areas.

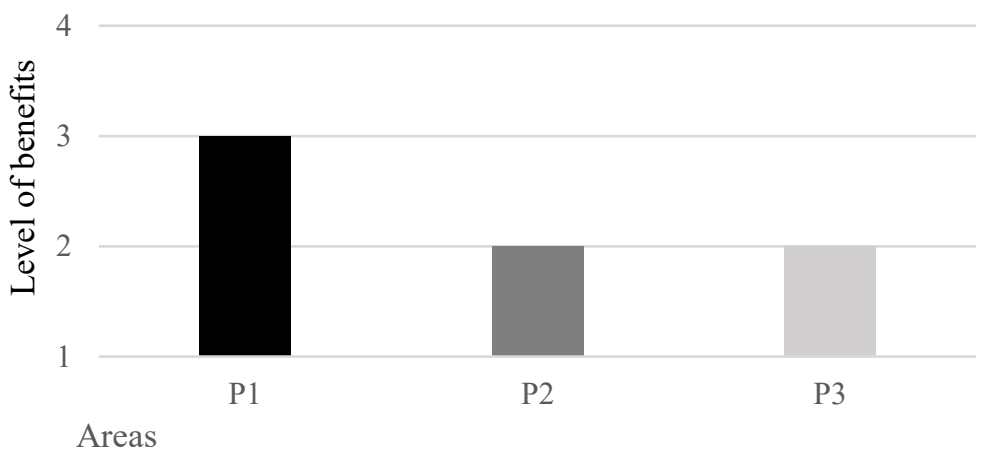

Fig. 7. Level of benefits provided by vegetation on areas P1, P2 and P3.

Notes: 4 - high level; 3 - average level; 2 - low level; 1 - insufficient.

\section{Discussion}

Research on CES in urban systems is yet under development and its applicability in planning processes is still a promise (Haase et al., 2014). This motivated us to look for ways of assessing vegetation areas and determining the level of benefits provided to residents in terms of recreational use. In order to understand the needs of the city for the provision of recreational 
services, it was necessary to do field research and observation of the use of vegetation areas. Environment and social conditions vary widely in urban spaces (Haase et al., 2014). We have verified this idea in the field, and we have found that every part of the city has its specific needs. But what connects all vegetation areas and living spaces is the need to provide residents with benefits in the form of relaxation, recreation, sports and other leisure activities.

The needs of residents in the housing estates perfectly define CES. This is confirmed by the claim that CES can be analysed using methods from different disciplines, including natural and environmental sciences, and also psychology, anthropology, landscape architecture and other social sciences. In other words, what makes the service 'cultural' is precisely its 'non-economic' character.

Similarly, research in Oslo (2015) assessed elements found in public spaces, but their assessment was based on the responses of users and their views on the importance of individual elements (Barton, 2015). It is in this assessment that we see a combination of different disciplines, such as psychology and the human perception of space. The methodology inspired us in the selection of evaluation elements, which was the basis for the creation of a new methodological approach in the field of recreational services in the housing estates in urbanised environments.

Various cities in Slovakia, such as Trnava and Bratislava, and also the winner of the architectural prize CE ZA AR 2018 for the exterior category, public space in Prešov, are examples of the fact that vegetation areas can be functional and modern and provide benefits for various recreational uses. The vegetation areas in the housing estate Chrenová do not meet the necessary quality. This is due to various factors. Vegetation areas are not being restored; only basic measures that do not meet the needs of rapidly changing trends and requirements are being taken. This methodological approach can be a tool for identifying missing elements and for evaluating the level of benefit of existing elements for recreational use in terms of CES. It is necessary to invest in vegetation areas, because these areas are the places where the inhabitants will find peace, relax, rest and necessary recreation during busy work weeks. Reconstruction, time and investment will return back in the form of the quality of life of inhabitants. The value of the quality of life is incalculable and reflected in many other areas.

\section{Conclusion}

Cultural ecosystem services are intangible benefits that a person perceives in everyday activity associated with outdoor movement. These services are also about understanding the way people live in urban spaces, and it is important to understand the relationship between man and the urban ecosystem.

On the basis of this knowledge, a new methodological approach to CES analysis was created in terms of recreation in urbanised environment. The quality (value) of elements and factors (quality of vegetation, composition of space, environmental factors, management and equipment), which is assessed on selected vegetation areas, determines the level of benefit, which further determines the degree of provision of recreational services. In this article, the quality of vegetation (trees and shrubs, lawn and flower beds), as well as its impact on recreational use, and the utility rates that vegetation provides to the population were elaborated. 
The methodological approach was used on three selected vegetation areas marked P1, P2 and P3 in the internal blocks of individual parts of Chrenová housing estate in Nitra. After assessing the vegetation areas, we have acquired a notion about the diverse quality of vegetation in urbanized environments. Vegetation areas are part of the same housing estate, so the results vary by one degree in maximum. However, a detailed analysis of the vegetation elements (trees and shrubs, lawn and flower beds) pointed to their shortcomings and differences. The best results were observed on P1. Provision of benefits of this vegetation area is at average level (3), which is an acceptable outcome in terms of recreation. The vegetation in the area is in good condition, especially the trees and shrubs have gained high quality (4) in our assessment. Their high quality and fitness in terms of horticultural, compositional and health aspects brings benefits for recreation such as improving the microclimate in the area, aesthetic effects, providing shade in the summer, trapping dust particles and others.

Other assessed areas are at the level of low benefit in the context of cultural ecosystem services. This was caused by several shortcomings in vegetation (mainly the horticultural and compositional aspects). Trees and shrubs are unevenly distributed on P2 and P3, resulting in large shading or sunburn. Thereby the grass areas are affected (drying out and moss overgrowth), and their assessment is decreased. The species composition (horticultural/ landscaping aspect) negatively influenced the evaluation result. The overall level of benefit for residents in terms of recreational use is low.

Vegetation quality is the basis for achieving a suitable environment for recreational and leisure activities. The methodological approach can be used for different vegetation areas in urbanised environments and can be used for various cultural ecosystem services after appropriate adjustments (e.g. after complementing other assessment elements).

The results can be used in landscape planning documents or other documents dealing with the quality of vegetation in urbanised areas.

\section{Acknowledgements}

The article was elaborated with support from the project VEGA 1/0706/20 Sustainable urban development in 21. Century - assessment of key factors, planning approaches and environmental contexts.

\section{References}

Bastian, O., Haase, D. \& Grunevald K. (2012). Ecosystem properties, potentials and services - The EPPS conceptual framework and an urban application example. Ecological Indicators, 21, 7-16. DOI: 10.1016/j.ecolind.2011.03.014.

Barton, D.N., Stange, E., Blumentrath, S. \& Vagnes Traaholt N. (2015). Economic valuation of ecosystem services for policy. A pilot study on green infrastructure in Oslo. NINA Report 1114.

Daniel, T.C., Muhar, A., Arnberger, A., Aznar, O., Boyd, J.W., Chan, K.M.A., Costanza, R., Elmquist, T., Flint, C.G., Gobster, P.H., Gret-Regamey, A., Lave, R., Muhar, S., Penker, M., Ribe, R.G., Schauppenlehner, T., Sikor, T., Soloviy, I., Spierenburg, M., Taczanowska, K., Tam, J. \& Von der Dunk A. (2012). Contributions of cultural services to the ecosystem services agenda. Proc. Natl. Acad. Sci. USA, 109(23), 8812-8819. DOI: 10.1073/ pnas.1114773109.

De La Barrera, F., Reyes-Paecke, S. \& Banzhaf E. (2016). Indicators for green spaces in contrasting urban settings. Ecological Indicators, 62, 212-219. DOI: 10.1016/j.ecolind.2015.10.027.

Burkhard, B., Kroll, F., Müller, F. \& Windshorst W. (2009). Landscapes' Capacities to Provide Ecosystem Services - A Concept for Land Cover Based Assessments. Landscape Online, 15, 1-22. DOI: 10.3097/LO.200915. 
Burkhard, B., Kroll, F., Nedkov, S. \& Müller F. (2012). Mapping ecosystem service supply, demand and budgets. Ecological Indicators, 21, 17-29. DOI: 10.1016/j.ecolind.2011.06.019.

Haase, D., Larondelle, N., Andersson, E., Artmann, M., Borgstrom, S., Breuste, J., Gomez-Baggethun, E., Gren, Å., Hamstead, Z., Hansen, R., Kabisch, N., Kremer, P., Langemeyer, J., Rall, E., Mcphearson, T., Pauleit, S., Qureshi, S., Schwarz, N., Voigt, A. \& Elmqvist T. (2014). A quantitative review of urban ecosystem service assessments: Concepts, models, and implementation. Ambio, 43(4), 413-433. DOI: 10.1007/s13280-014-0504-0.

Haines-Young, R. \& Potachin M.B. (2018). Common International Classification of Ecosystem Services (CICES) V5.1 and guidance on the application of the revised structure. https://cices.eu/content/uploads/sites/8/2018/01/Guidance-V51-01012018.pdf

Izakovičová, Z., Mederly, P. \& Petrovič F. (2017). Long-term land use changes driven by urbanisation and their environmental effects (Example of Trnava city, Slovakia). Sustainability, 9(9), 1553. DOI: 10.3390/su9091553.

Jarabica, V. (2011). Chrenová I v Nitre. Urbanita, 23(1), p. 30-33.

Kubišta, R. (2008). Inventarizačné metódy v záhradnej architektúre. Acta Horticulturae et Regiotecturae, 11(Suppl.), $12-15$.

Machovec, J. (1982). Sadovnická dendrologie. Praha: SPN.

Millennium Ecosystem Assessment (2005). Ecosystems and Human Well-being: Synthesis. Washington: Island Press. https://www.millenniumassessment.org/documents/document.356.aspx.pdf

Murgaš, F. \& Klobučník M. (2018). Quality of life in the city, quality of urban life or well-being in the city: conceptualization and case study. Ekológia (Bratislava), 37(2), 183-200. DOI: 10.2478/eko-2018-0016.

Piscová, V., Hrnčiarová, T., Hreško, J., Dobrovodská, M., Izakovičová, Z., Izsoff, M., Kalivoda H., Kanka, R., Kenderessy, P., Považan, R., Roháč, J., Slabejová, M., Slivinský, J., Špulerová, J., Švajda, J., Topercer, J., Vlachovičová, M., Borovský, I. \& Hurta V. (2018). Využívanie vysokohorskej krajiny a jeho dôsledky na zmenu prostredia (na príklade Tatier a Nizkych Tatier). Bratislava: Veda, vydavatelstvo SAV.

Plieninger, T., Dijks, S., Oteros-Rozas, E. \& Bieling C. (2013). Assessing, mapping, and quantifying cultural ecosystem services at community level. Land Use Policy, 33, 118-129. DOI: 10.1016/j.landusepol.2012.12.013.

Špulerová, J. (2006). Funkcie nelesnej drevinovej vegetácie v krajine. Životné Prostredie, 40(1), 37-40.

Turanovičová, M. \& Rózová Z. (2017). Metodické východiská hodnotenia kultúrnych ekosystémových služieb v urbanizovanom prostredí. Životné Prostredie, 51(4), 232-239.

Turanovičová, M. \& Rózová Z. (2018). Vplyv kvality manažmentu na úžitok kultúrnych ekosystémových služieb. Geografické Informácie, 22(2), 315-326. DOI: 10.17846/GI.2018.22.2.315-326.

Zulian, G., Stange, E., Woods, H., Carvalho, L., Dick, J., Andrews, Ch., Baró, F., Vizcaino, P., Barton, D.N., Nowel, M., Rusch, G.M., Autunes, P., Fernandes, J., Ferraz, D., Ferreira dos Santos, R., Aszalós, R., Arany, I., Czúcz, B., Priess, J.A., Hoyer, Ch., Bürger-Patricio, G., Lapola, D., Mederly, P., Halabuk, A., Bezák, P., Kopperoinen, L. \& Viinikka A. (2018). Practical application of spatial ecosystem service models to aid decision support. Ecosystem Services, 29(Part C), 465-480. DOI: 10.1016/j.ecoser.2017.11.005. 